\title{
Produktivitas Tanaman Rambutan (Nephelium lappaceum L.) Lahan Pekarangan Kabupaten Bangkalan
}

\section{(Productivity Of Rambutan Plants (Nephelium lappaceum L.) in the Homegarden in Bangkalan Regency)}

\author{
Ahmad Arsyadmunir ${ }^{1 *}$ dan Abdul Ghofur ${ }^{1}$ \\ ${ }^{1}$ Program studi Agroekoteknologi, Fakultas Pertanian, Universitas Trunojoyo Madura \\ J1. Raya Telang PO BOX 2, Kamal, Bangkalan, Jawa Timur, Indonesia \\ *Email korespondensi: ar.arsyadinulfah@gmail.com
}

Diterima 26 April 2019/Disetujui 10 Mei 2019

\begin{abstract}
ABSTRAK
The homegarden is a plot of land located around the house with clear ownership limitation is a potential land as one of the fields for agricultural production. The purpose of this study was to determine the use and cropping patterns of the homegarden and to determine the yield of Rambutan (Nephelium lappaceum L.) in Socah District, Bangkalan Regency. This research was conducted from January to July 2018. This research was conducted on three villages in Socah, Bangkalan district. This research uses descriptive method with survey technique. The location of the study was determined by purposive sampling method that is based on the homegarden planted with Rambutan plants. The determination of informant or resources used snowball sampling technique. The data was obtained and analyzed in descriptive qualitative method. The land of communities in Socah was planted some plants of fruit by yearly system of planting. It is done on intercropping between lychee, Mango, Salak, and Sawo with distance planting an average of $6 \mathrm{~m}$ between plants. The average of Rambutan productivity in their yards in the district of Socah described sequentially the Jaddih village $=29.97(\mathrm{kw} / \mathrm{ph})$, Keleyan village $=$ $26.45(\mathrm{kw} / \mathrm{ph})$ and the Bilaporah village $=22.86(\mathrm{kw} / \mathrm{ph})$.
\end{abstract}

Keywords: lychee productivity, the homegarden, utilization

\begin{abstract}
ABSTRAK
Pekarangan merupakan tanah yang terletak di sekitar rumah. dengan batas pemilikan yang jelas potensial untuk produksi pertanian. Tujuan dari penelitian ini adalah untuk mengetahui pemanfaatan dan pola tanam lahan pekarangan serta mengetahui hasil produksi tanaman rambutan (Nephelium lappaceum L.) di Kecamatan Socah Kabupaten Bangkalan. Penelitian ini dilaksanakan pada bulan Januari sampai bulan Juli 2018. Penelitian ini dilakukan pada 3 (tiga) desa di kecamatan Socah kabupaten Bangkalan. Lokasi penelitian ditentukan dengan metode purposive sampling yaitu berdasarkan lahan pekarangan yang ditanami tanaman rambutan. Penentuan informan atau narasumber menggunakan teknik snowball sampling. Data yang diperoleh kemudian dianalisis secara deskriptif kualitatif. Masyarakat di Kecamatan Socah memanfaatkan lahan pekarangannya dengan ditanami beberapa tanaman buah tahunan. Sistem pola tanam yang dilakukan adalah secara tumpang sari antara tanaman rambutan, mangga, salak, sawo, dengan jarak tanam rata-rata 6 m antar tanaman. Rata-rata produktivitas tanaman rambutan pada lahan pekarangan di Kecamatan Socah tertinggi secara berurutan yaitu desa Jaddih = $29.97(\mathrm{kw} / \mathrm{ph})$, desa Keleyan $=26.45(\mathrm{kw} / \mathrm{ph})$, dan desa Bilaporah $=22.86(\mathrm{kw} / \mathrm{ph})$.
\end{abstract}

Kata Kunci: pekarangan, pemanfaatan lahan pekarangan, produktivitas rambutan.

\section{PENDAHULUAN}

Pertumbuhan penduduk berlangsung dengan pesat, maka diperlukan usaha penataan lingkungan pemukiman dengan mempertimbangkan keseimbangan ekologis terutama adanya areal terbuka hijau untuk lahan pemukiman dan pemanfaatan lahan pekarangan dengan menanami tanaman peneduh, tanaman buah-buahan, sayuran dan berbagai jenis tanaman lainnya. Dengan demikian fungsi tumbuhan sebagai penghasil oksigen dan pereduksi karbondioksida tetap dapat berlangsung pada lahan pemukiman. Lahan pekarangan berfungsi multiguna menjaga kualitas lingkungan yang baik dan membantu meningkatkan produksi pertanian (Soemarwoto dan Christanty, 1985).

Pekarangan dapat dipandang sebagai lumbung hidup sekaligus merupakan induk yang sewaktu-waktu dapat diambil manfaatnya apabila usaha tani di sawah atau tegalan mengalami kegagalan akibat serangan hama atau penyakit, banjir, kekeringan dan bencana alam lainnya. Lahan pekarangan di Kabupaten Bangkalan masih cukup luas dan belum dimanfaatkan secara optimal. Data dari Dinas Pertanian Kabupaten Bangkalan tahun 2016 menunjukkan bahwa ada 21 komoditas tanaman buah di Kecamatan Socah 
yaitu belimbing, alpukat, duku, durian, jambu biji, jambu air, jeruk keprok, jeruk besar, mangga, manggis, nangka, pisang, nanas, pepaya, rambutan, salak, sawo, sirsak, sukun, melinjo, dan markisa. Data tersebut menunjukkan bahwa yang paling tinggi produksinya adalah tanaman buah rambutan yaitu sebanyak 68.005 pohon menghasilkan dengan produktivitas sebesar $0,50 \mathrm{kwintal}$ perpohon pada tahun 2015 dan menurun pada tahun 2016 yaitu 133.255 pohon menghasilkan dengan produktivitas 0,35 kwintal perpohon.

Berdasarkan paparan diatas dapat dikatakan bahwa sebagian masyarakat kurang menyadari betapa pentingnya pekarangan. Kebanyakan rumah di daerah Socah memiliki pekarangan yang cukup luas, tetapi masyarakat belum memanfaatkan dengan baik. Oleh karena itu perlu adanya penelitian tentang pemanfaatan lahan pekarangan dan produksi tanaman rambutan di Kecamatan Socah Kabupaten Bangkalan Madura. Bagaimana produksi tanaman rambutan (Nephelium lappaceum L.), pemanfaatan dan pola tanam dan produksi tanaman rambutan (Nephelium lappaceum L.) pada lahan pekarangan di Kecamatan Socah.

\section{METODE PENELITIAN}

Penelitian ini dilakukan di tiga desa di kecamatan Socah kabupaten Bangkalan yang banyak ditanami rambutan pada bulan Januari sampai bulan Juli 2018. Alat yang digunakan kamera digital, alat tulis dan computer menggunakan data sekunder dan data primer. Data sekunder di peroleh dari Dinas Pertanian Kabupaten, Badan Pusat Statistik, dan Kantor Kecamatan Socah. Data primer di peroleh dari survey dan wawancara.

\section{Metode Penelitian}

Penelitian deskriptif dengan teknik survey untuk memperoleh gambaran lahan pekarangan. Kriteria sampel yang diteliti yaitu terdapat rumah pokok, mushollah, kandang ternak, dapur, kamar mandi luar, dan tanaman pekarangan di dalamnya. Sedangkan lokasi ditentukan dengan metode purposive sampling yaitu pada lahan pekarangan yang ditanami tanaman rambutan.

Narasumber menggunakan teknik snowball sampling. Langkah awal yang dilakukan yaitu dengan cara pendekatan ke informan kunci agar mendapatkan informasi tentang sampel yang diinginkan. Pemilihan informan sebagai sumber data dalam penelitian ini adalah berdasarkan pada asas subyek yang menguasai permasalahan, memiliki data dan bersedia memberikan informasi lengkap dan akurat. Informan yang bertindak sebagai sumber data dan informasi harus memenuhi syarat, yang menjadi narasumber dalam penelitian ini adalah masyarakat setempat dan BPP kecamatan Socah. Data yang dikumpulkan meliputi ukuran luas lahan pekarangan, pemanfaatan lahan pekarangan, pola tanam lahan pekarangan, dan produksi tanaman buah rambutan pada lahan pekarangan di wilayah Kecamatan Socah.

\section{Tahapan Penelitian}

\section{Survei Pendahuluan}

Tahap ini merupakan awal dari rancangan kegiatan yang akan dilakukan. Tahap persiapan survei berfungsi untuk memberikan gambaran apa saja yang akan dilakukan waktu survei lapangan agar berjalan dengan lancar dan sesuai dengan jadwal yang telah dibuat, dalam hal ini adalah mencari informasi kepada masyarakat setempat tentang lahan pekarangan di kecamatan Socah.

\section{Mengumpulkan Data Sekunder}

Dalam melaksanakan studi kepustakaan, dimaksudkan untuk memperoleh data sekunder dalam menunjang data primer yang telah didapat dari survey lapangan. Dalam melakukan studi kepustakaan ini, penulis mengumpulkan data dengan membaca literatur dan bukubuku yang berhubugan dengan masalah yang dibahas. Data sekunder diperoleh dari Dinas Pertanian Kabupaten Bangkalan, Badan Pusat Statistika Kabupaten Bangkalan, dan BPP Kecamatan Socah. Data yang dikumpulkan meliputi data luasan wilayah, hasil produksi tanaman buah rambutan, dan data pendukung lainnya.

\section{Survey Lapang (Pengumpulan Data Primer)}

Peneliti melakukan pencarian data dengan mengandalkan masyarakat di area setempat sebagai sumber informasi yang ditemukan dari hasil survey. Dari 3 (tiga) desa di kecamatan Socah diambil masing-masing 10 sampel. Data yang dibutuhkan dalam penelitian ini meliputi luas lahan pekarangan, pola tanam lahan pekarangan, jumlah tanaman rambutan yang berada di lahan pekarangan, umur tanaman rambutan, perawatan tanama rambutan, serta hasil produksi tanaman rambutan yang berada di lahan pekarangan kecamatan Socah.

Penelitian menggunakan metode deskriptif kualitatif dengan membandingkan antara data yang ada di lapangan dengan data kepustakan, selanjutnya dianalisis secara deskriptif untuk mengetahui dan menarik kesimpulan terkait pemanfaatan dan pola tanam lahan pekarangan serta produksi tanaman buah rambutan pada lahan pekarangan di kecamatan Socah.

\section{HASIL DAN PEMBAHASAN}

Banyaknya hasil produksi rambutan pada tiga desa di kecamatan Socah tidak terlepas dari beberapa faktor, yakni faktor luas lahan pekarangan dan produktifitas tiap pohon tersebut yang mempengaruhi kuantitas produksi di suatu daerah termasuk kecamatan Socah yang pada akhirnya akan menentukan pula kuantitas produksi rambutannya, kemudian faktor yang tidak kalah penting yang akan diuraikan pada hasil penelitian ini adalah faktor jumlah pohon rambutan, perawatan, dan pola tanam lahan pekarangan yang dilakukan oleh masyarakat Kecamatan Socah. Berikut data luasan lahan pekarangan pada tiga desa di Kecamatan Socah yang didapatkan dari hasil survey. 
Tabel 1. Perbandingan Luas Lahan Pekarangan dengan Jumlah Pohon Rambutan di Kecamatan Socah

\begin{tabular}{lcccc}
\hline Desa & $\begin{array}{c}\text { Luas Lahan } \\
\text { Pekarangan }\end{array}$ & $\begin{array}{c}\text { Jumlah Pohon } \\
\text { Rambutan }\end{array}$ & $\begin{array}{c}\text { Jumlah Pohon Rambutan } \\
\text { Menghasilkan }\end{array}$ & $\begin{array}{c}\text { Umur Pohon } \\
\text { Rambutan }\end{array}$ \\
Keleyan & 1953 & 67 & 51 & 22 \\
Bilaporah & 1960 & 52 & 52 & 29 \\
Jaddih & 1758 & 50 & 50 & 31 \\
\hline Jumlah & 5671 & 169 & 153 & - \\
\hline Rata-rata & 1890 & 56 & 51 & 27 \\
\hline
\end{tabular}

Sumber : Diolah dari data primer, 2018

Tabel 2. Perawatan Tanaman Rambutan pada Lahan Pekarangan di Kecamatan Socah Berdasarkan Sampel

\begin{tabular}{clll}
\hline Sampel & Keleyan & Bilaporah & Jaddih \\
\hline 1 & Dipangkas & Dipangkas & Dipangkas \\
2 & Dipangkas & Dipangkas & Dipangkas \\
3 & Dipangkas & Dipangkas & Dipangkas, dipupuk \\
4 & Dipupuk, dipangkas & Dipangkas & Dipangkas \\
5 & Dipangkas & Dipangkas & Dipangkas \\
6 & Dipangkas & Dipangkas, dipupuk & Dipangkas, dipupuk \\
7 & Dipupuk, dipangkas & Dipangkas & Dipangkas \\
8 & Dipangkas & Dipangkas, dipupuk & Dipangkas, dipupuk \\
9 & Dipangkas & Dipangkas & Dipangkas \\
10 & Dipangkas & Dipangkas, dipupuk & Dipangkas \\
\hline & Dipangkas (80\%) & Dipangkas (70\%) & Dipangkas (70\%) \\
\hline
\end{tabular}

Sumber : Diolah dari data primer, 2018

Tabel 3. Pola Tanam Lahan Pekarangan di Kecamatan Socah

\begin{tabular}{|c|c|c|c|}
\hline Desa & Pola Tanam & Jarak Tanam (m) & Komoditas yang ditanam \\
\hline Keleyan & $\begin{array}{l}-\mathrm{Ts}(90 \%) \\
-\mathrm{Mk}(10 \%)\end{array}$ & $\begin{array}{l}-5 \mathrm{~m}(20 \%) \\
-6 \mathrm{~m}(60 \%) \\
-7 \mathrm{~m}(20 \%)\end{array}$ & $\begin{array}{l}\text { Rambutan, Mangga, Kelengkeng, Pisang, Jeruk, Sirsak, } \\
\text { Sawo }\end{array}$ \\
\hline Bilaporah & -Ts $(100 \%)$ & $\begin{array}{l}-6 \mathrm{~m}(40 \%) \\
-7 \mathrm{~m}(60 \%)\end{array}$ & $\begin{array}{l}\text { Rambutan, Salak, Mangga, Durian, Jambu, Pisang, } \\
\text { Belimbing, Sukun, Kelengkeng, Nangka, Pisang, Pepaya, }\end{array}$ \\
\hline Jaddih & $\begin{array}{l}-\mathrm{Ts}(90 \%) \\
-\mathrm{Mk}(10 \%)\end{array}$ & $\begin{array}{l}-6 \mathrm{~m}(40 \%) \\
-7 \mathrm{~m}(60 \%)\end{array}$ & Rambutan, Mangga, Pisang, Jeruk, Alpukat, Nangka, Jambu \\
\hline Persentase & $\begin{array}{l}-\operatorname{Ts}(93 \%) \\
-\operatorname{Mk}(7 \%)\end{array}$ & $\begin{array}{l}-5 \mathrm{~m}(6 \%) \\
-6 \mathrm{~m}(47 \%) \\
-7 \mathrm{~m}(47 \%)\end{array}$ & \\
\hline
\end{tabular}

Keterangan : Ts (Tumpang sari), Mk (Monokultur)

Sumber : Diolah dari data primer, 2018 
Tabel 4. Perbandingan Luas Tanam (Ph), Luas Panen (Ph), Produktivitas, dan Produksi (Kw) Tanaman Rambutan pada Lahan Pekarangan di Kecamatan Socah

\begin{tabular}{lcccc}
\hline Desa & $\begin{array}{c}\text { Jumlah Tan } \\
(\mathrm{Ph})\end{array}$ & $\begin{array}{c}\text { Jumlah Tan } \\
\text { Menghasilkan }(\mathrm{Ph})\end{array}$ & $\begin{array}{c}\text { Produktivitas } \\
(\mathrm{Kw} / \mathrm{Ph})\end{array}$ & Produksi (Kw) \\
\hline Keleyan & 67 & 51 & 5.19 & 264.51 \\
Bilaporah & 52 & 52 & 4.40 & 228.59 \\
Jaddih & 50 & 50 & 5.99 & 299.68 \\
\hline Jumlah & 169 & 153 & 15.58 & 792.78 \\
\hline
\end{tabular}

Sumber : Diolah dari data primer, 2018

Pada Tabel 1 menunjukkan bahwa luasan lahan pekarangan di kecamatan Socah rata-rata seluas $1890 \mathrm{~m}^{2}$. Rata-rata luas lahan pekarangan terluas terdapat pada desa Bilaporah dengan rata-arata luas lahan pekarangan $1960 \mathrm{~m}^{2}$, dengan jumlah pohon rambutan pada lahan pekarangan sebanyak 52 pohon rambutan yang seluruhnya merupakan pohon rambutan menghasilkan setiap tahunnya yaitu pada musim rambutan yaitu pada bulan Nopember sampai bulan Februari, sedangkan umur pohon rambutan pada lahan pekarangan desa Bilaporah rata-rata sudah berumur 29 tahun. Rata-rata luas lahan pekarangan desa Jaddih adalah seluas $1758 \mathrm{~m}^{2}$ dengan jumlah 50 pohon rambutan menghasilkan pada lahan pekarangan desa Jaddih. Rata-rata jumlah pohon rambutan pada lahan pekarangan kecamatan Socah terbanyak terdapat pada desa Keleyan dengan jumlah 67 pohon rambutan namun hanya 51 diantaranya yang berbuah atau menghasilkan hal ini dikarenakan pada satu titik sampel di desa Keleyan didata terdapat 20 pohon rambutan namun hanya 4 pohon rambutan saja yang menghasilkan atau berbuah, hal ini dikarenakan pohon tersebut baru di lakukan pangkas bentuk untuk membentuk pohon yang diinginkan.

Umur pohon rambutan tertua pada lahan pekarangan kecamatan Socah terdapat pada desa Jaddih, rata-rata umur pohon rambutan pada lahan pekarangan desa Jaddih adalah 31 tahun, sedangkan umur pohon rambutan termuda pada lahan pekarangan kecamatan Socah terdapat pada desa Keleyan yang rata-rata pohon rambutan pada lahan pekarangan berumur 22 tahun setelah tanam. Berdasarkan tabel diatas bisa dilihat bahwa pohon rambutan pada lahan pekarangan kecamatan Socah rata-rata masih berproduksi atau menghasilkan.

Tabel 2 menunjukkan bahwa perawatan pohon rambutan yang dilakukan oleh masyarakat pada lahan pekarangan di kecamatan Socah yaitu dipupuk, dan dipangkas. Berdasarkan hasil survey perawatan pohon rambutan pada desa Keleyan adalah dipangkas sebanyak $80 \%$ dengan dipangkas dan dipupuk sebesar 20\%. Perawatan pohon rambutan dipangkas $70 \%$ dengan dipupuk dan dipangkas $30 \%$ pada desa Bilaporah, sedangkan pada desa Jaddih perawatan pada pohon rambutan dipangkas sebesar $70 \%$ dan dipupuk, dipangkas sebesar $30 \%$.

Perlakuan pemupukan pada ketiga desa tersebut hampir sama, yaitu dilakukan satu kali dalam satu tahun. Pemupukan yang dilakukan yaitu dengan cara dipupuk di sekitar pohon berjarak setengah meter pada sekeliling pohon rambutan. Pemupukan yang dilakukan setelah proses pemanenan, yaitu setelah buah pada pohon rambutan telah dipanen semuanya. Masyarakat Socah merawat pohon rambutan pada lahan pekarangannya dengan cara memangkas atau membuang tanaman pengganggu seperti benalu. Masyarakat socah melakukan pemangkasan ketika sudah melihat tanamannya tidak sehat, adapun ciri-ciri pohon rambutan yang tidak sehat adalah ketika sebagian ranting dari pohon tersebut menguning kemudian lamakelamaan pada ranting tersebut mongering dan harus segera dilakukan pemangkasan pada ranting tersebut. Perawatan pohon rambutan di lahan pekarangan kecamatan Socah.

Pola tanam adalah pengaturan penanaman pada suatu lahan pertanian dalam kurun waktu tertentu. Pola tanam merupakan suatu bagian atau sub sistem dari sistem budidaya tanaman, sistem budidaya tanaman ini dapat dikembangkan satu atau lebih sistem pola tanam. Pola tanam ini diterapkan dengan tujuan memanfaatkan sumber daya secara optimal dan untuk menghindari resiko kegagalan, namun yang penting persyaratan tumbuh antara kedua tanaman atau lebih terhadap lahan hendaklah mendekati kesamaan. Secara umum pola tanam terdiri dari dua sistem yaitu pola tanam monokultur dan pola tanam polikultur (Vitriyatul, 2012).

Tabel 3 di atas menjelaskan tentang pola tanam lahan pekarangan yang ada di kecamatan Socah. Tabel 4.4 di atas menunjukkan bahwa pada desa Keleyan pola tanam pada lahan pekarangan sebesar $90 \%$ menggunakan pola tanam tumpang sari dan $10 \%$ menggunakan pola tanam monokultur. Pola tanam pada lahan pekarangan desa keleyan umumnya menggunakan pola tanam tumpang sari dengan jarak tanam $5 \mathrm{~m}$ antar tanaman sebesar $20 \%$, jarak tanam 6 $\mathrm{m}$ sebesar $60 \%$ dan pada sebagian lagi menggunakan jarak tanam $7 \mathrm{~m}$ sebesar $20 \%$. Berdasarkan hasil survey pada desa Bilaporah kecamatan Socah, pola tanam pada lahan pekarangan $100 \%$ adalah tumpang sari dengan jarak tanam $6 \mathrm{~m}$ sebesar $40 \%$, sedangkan jarak tanam $7 \mathrm{~m}$ antar tanaman pada lahan pekarangan desa Bilaporah sebesar $60 \%$. Pada desa Jaddih jarak tanam yang banyak digunakan adalah jarak tanam $7 \mathrm{~m}$ sebesar $60 \%$ dan sisanya adalah $40 \%$ menggunakan jarak tanam $6 \mathrm{~m}$ antar tanaman. Berdasarkan hasil survei, pola tanam yang digunakan pada lahan pekarangan kecamatan Socah sebesar 93\% adalah pola 
tanam tumpang sari dan sisanya adalah pola tanam menggunakan pola tanam monokultur.

Secara topografi desa Keleyan sebagian besar berupa tanah dataran dengan struktur tanah lempung berpasir. Dengan kondisi tanah seperti ini banyak sekali dimanfaatkan masyarakat desa Keleyan dengan untuk bercocok tanam tanaman buah tahunan maupun tanaman semusim lainnya. Dapat dilihat dari tabel diatas bahwa banyak ditemukan tanaman buah yang msyarakat usahakan di lahan pekarangannya seperti tanaman mangga, kelengkeng, pisang, jeruk, sirsak, sawo.

Desa Bilpaorah sebagian besar berupa tanah dataran dengan struktur tanah lempung berpasir. Masyarakat desa Bilaporah memanfaatkannya dengan bercocok tanam padi maupun tanaman semusim lainnya. Tanah desa Bilaporah cukup subur. Sehingga masyarakat banyak menanam pohon buah. Terutama pohon buah salak yang mayoritas mendominasi kebun-kebun maupun di lahan pekarangan desa Bilaporah. Masyarakat mengusahakan tanaman buah seperti mangga, durian, jambu, pisang, belimbing, sukun, kelengkeng, nangka, pisang, dan papaya.

Tanah desa Jaddih termasuk cukup subur. Sehingga masyarakat banyak menananm pohon buah durian yang mayoritas mendominasi kebun-kebun maupun di lahan pekarangan desa Jaddih. Dapat dilihat dari tabel diatas banyak masyarakat mengusahakan tanaman buah pada lahan pekarangannya seperti rambutan, mangga, pisang, jeruk, alpukat, nangka, dan jambu. Secara topografi desa Jaddih sebagian besar berupa tanah merah padat dan mudah menyerap air.

Produksi dan produktivitas sangat penting dalam bidang pertanian karena keduanya saling berkaitan untuk mengetahui hasil dari budidaya tanaman pada suatu luasan dan wilayah tertentu. Produksi merupakan hasil yang diperoleh setelah melakukan budidaya tanaman untuk mengetahui hasil akhir dari suatu usaha pertanian dalam satu petakan tertentu dengan satuan $\mathrm{kg}$. Sedangkan produktivitas merupakan hasil akhir yang diperoleh dari jumlah produksi yang dilihat dari suatu hamparan luasan lahan dengan mempertimbangkan output dan input yang diperoleh yang satuannya adalah kg. hektar ${ }^{-1}$ (Ton/Ha/Th).

Tabel 4 menunjukkan bahwa pada lahan pekarangan desa Keleyan terdapat jumlah tanaman rambutan sebanyak 67 pohon dengan pohon menghasilkan berjumlah 51 pohon. Jumlah tanaman rambutan pada lahan pekarangan desa Jaddih lebih sedikit dibanding dua desa lainnya yaitu 50 pohon akan tetapi dari jumlah pohon tersebut semuanya merupakan pohon menghasilkan atau berbuah. Desa Bilaporah memiliki jumlah tanaman rambutan sebesar 52 pohon rambutan yang semua pohon tersebut menghasilkan atau berbuah.

Produktivitas pohon rambutan pada lahan pekarangan kecamatan Socah tertinggi terdapat pada desa Jaddih sebesar $5.99(\mathrm{kw} / \mathrm{ph})$, dengan jumlah produksi sebesar $299.78(\mathrm{kw})$. Produktivitas pohon rambutan pada lahan pekarangan kecamatan Socah terendah terdapat pada desa Bilaporah, dengan jumlah produktivitas sebesar $4.40(\mathrm{kw} / \mathrm{ph})$ dengan produksi sebesar $228.59(\mathrm{kw})$. Sedangkan pada lahan pekarangan desa Keleyan produktivitas pohon rambutan sebesar $5.19(\mathrm{kw} / \mathrm{ph})$ dengan jumlah produksi sebesar $264.51(\mathrm{kw})$. Berdasarkan tabel di atas menunjukkan bahwa produksi dan produktivitas tertinggi terdapat pada desa Jaddih. Hal ini terjadi karena pohon rambutan pada lahan pekarangan di desa Jaddih rata-rata dirawat dengan cara dipangkas, dan dipupuk

Pembahasan umum berdasarkan hasil pengamatan, pemanfaatan lahan pekarangan pada tiga kecamatan Socah memperlihatkan bahwa rata-rata intensitas pemanfataan lahan pekarangan masih rendah. Hal ini ditunjukkan oleh masih adanya beberapa lahan kosong atau yang tidak ditanami, sebagian tanaman masih muda (belum berproduksi), dan sebagian lagi kurang optimal pertumbuhannya, serta sebaran pohon pada lahan pekarangan tidak merata. Hal ini sejalan dengan pendapat yang dikemukakan oleh Tim Fakultas Pertanian IPB (1992) dalam Lakitan (1995) bahwa walaupun keragaman tanaman di lahan pekarangan cukup baik, namun intensitas penanaman (banyaknya tanaman yang diusahakan) dan produktivitasnya masih rendah. Selain itu dari segi gizi, terutama protein, mineral dan vitamin. Selanjutnya dijelaskan oleh Lakitan (1995) bahwa, untuk meningkatkan intensitas pemanfaatan dan produktivitas lahan pekarangan dapat dilakukan dengan cara penataan kembali pola penanaman lahan tersebut dengan menggunakan jenis buah buahan unggul, mempunyai nilai ekonomi dan nilai gizi yang tinggi, demikian pula untuk komoditas tanaman sayurannya. Hosen (2007) menjelaskan bahwa untuk meningkatkan pengembangan pemanfaatn lahan pekarangan dapat dilakukan dengan pilihan komoditas yang toleran dengan faktor-faktor pembatas di lahan tersebut.

Berdasarkan hasil pengamatan penelitian dari tiga desa rata-rata pohon rambutan ditanaman oleh masyarakat per pekarangan adalah 6-7 pohon. Pada umumnya tanaman buah yang terdapat di lahan pekarangan kecamatan Socah merupakan jenis tanaman buah tahunan, sehingga komposisi tanaman buah yang ada di lahan pekarangan hampir stabil dalam kurun waktu yang cukup lama.

Produksi yang rendah dapat disebabkan oleh beberapa hal berikut, yaitu kurangnya sumber daya manusia yang ahli dalam bidang pertanian, minimalnya pengembangan teknologi pertanian, sistem budidaya yang tidak memenuhi SOP yang di anjurkan, kondisi lingkungan dan penataan lahan yang kurang baik serta sistem usahatani yang kurang optimal dan lain sebagainya.

Berdasarkan hasil pengamatan menunjukkan bahwa di desa Keleyan sebagian besar responden melakukan kegiatan pemeliharaan tanaman rambutan walaupun kurang optimal. Pemeliharaan tanaman rambutan yang dilakukan di desa Keleyan seperti pemupukan yang hanya dilakukan satu kali setiap tahun yaitu setelah proses pemanenan, sedangkan pada desa Bilaporah dan desa Jaddih perlakuan pemupukan masingmasing 30\% tidak seperti pada desa Keleyan yang hanya $20 \%$ dalam perlakuan pemupukan. Pada tiga lokasi penelitian, penyiraman pada tanaman rambutan dilakukan seperlunya, sedangkan untuk pengendalian hama dan penyakit pada tanaman rambutan jarang dilakukan. Kegiatan pemeliharaan di lahan pekarangan di lokasi penelitian umumnya dilakukan oleh para ibu rumah tangga beserta 
anak-anaknya. Adapun hasil panen dari tanaman yang ditanam di lahan pekarangan, sebagian untuk dikonsumsi sendiri, sebagian lagi dijual dan sisanya diberikan kepada tetangga, family atau untuk kepentingan sosial lainnya.

Pengetahuan masyarakat kecamatan Socah tentang penanaman berbagai jenis komoditas tanaman buah pada lahan pekarangan diperoleh secara turun temurun. Berdasarkan pengetahuan dan pengalaman dalam kurun waktu yang lama tersebut, mereka mengetahui bahwa jenisjenis tanaman yang sesuai dengan kondisi lahan dan agroklimat setempat, baik yang merupakan pangan pokok maupun penunjang. Ada pun jenis tanaman bahan pangan pokok (sumber karbohidrat) yang ditanam di lahan pekarangan yaitu pisang, yang biasa dicampurkan dalam pangan pokok. Jenis tanaman bahan pangan pokok yang ditanam di pekarangan, lebih banyak untuk jenis tanaman pangan yang dikonsumsi sendiri. Namun saat musim kemarau, dimana lahan pertanian tidak bisa berproduksi, hasil dari lahan pekarangan menjadi tumpuan untuk memenuhi kebutuhan pangan keluarga secara langsung maupun tidak.

Sistem tanam yang dikenal oleh masyarakat setempat adalah sistem kebun campuran. Berbagai tanaman dibudidayakan dengan jarak tanam yang tidak teratur. Perawatan yang dilakukan terhadap tanaman berupa permbersihan tanaman pengganggu, tanpa atau dengan aplikasi pemupukan sederhana, biasanya menggunakan pupuk kandang hasil ternak sendiri, tanpa pupuk dan obatobatan buatan pabrik. Pemanfataan lahan pekarangan yang dilakukan oleh masyarakat Socah di lokasi penelitian juga mengakomodasi berbagai fungsi, walaupun proporsinya untuk masing-masing desa tidak selalu sama. Fungsi pekarangan menurut masyarakat setempat adalah budidaya tanaman pohon buah-buahan. Pola penanaman pohon buahbuahan tersebut diselaraskan dengan garis kontur lahan pekarangan.

Hasil penelitian pola pertanian di lahan pekarangan kecamatan Socah umumnya berupa tumpang sari. Petani menanam berbagai macam komoditas berupa tanaman tahunan maupun semusim pada lahan pekarangannya dengan jarak tanam rata-rata $6 \mathrm{~m}$ antar tanaman, demikian juga untuk tanaman rambutan. Komoditas yang ditanam pada lahan pekarangan Kecamatan Socah berupa tanaman pangan, hortikultura, dan perkebunan. Tentu saja dalam pemilihan komoditas, petani sudah mempertimbangkan tujuan utama penanaman apakah untuk sekedar memenuhi kebutuhan pangan sehari-hari, untuk komersial, dan lain sebagainya.

\section{KESIMPULAN}

Kecamatan Socah memanfaatkan lahan pekarangannya dengan ditanami beberapa tanaman buah tahunan. Sistem pola tanam yang dilakukan adalah secara tumpang sari antara tanaman rambutan, mangga, salak, sawo, dengan jarak tanam rata-rata $6 \mathrm{~m}$ antar tanaman. Produksi tanaman rambutan pada lahan pekarangan di Kecamatan Socah tertinggi secara berurutan yaitu desa Jaddih $=299.68(\mathrm{kw})$, desa Keleyan $=264.51(\mathrm{kw})$, dan desa Bilaporah $=228.59$ (kw).

\section{DAFTAR PUSTAKA}

Agus, 2001. Memanfaatkan Lahan Pekarangan sebagai Apotik Hidup. Jakarta (ID): Penebar Swadaya.

Arifin, H.S., A. Munandar, N.H.S. Arifin, Kaswanto, 2009. Pemanfatan Pekarangan di Pedesaan Buku Seri II. Biro Perencanaan Sekjen Deptan Bekerjasama dengan Departemen Arsitektur Landscape, Faperta IPB. Bahan Penyuluhan: Bogor. BPS, 2016. Kecamatan Socah dalam Angka. Kabupaten Bangkalan.

Dinas Pertanian dan Peternakan. 2017. Laporan Tahunan 2017.

Hamidi. 2004. Metode penelitian kualitatif: aplikasi praktis pembuatan proposal dan laporan penelitian.

Hosen, N. 2007. Potensi dan Masalah Pengembangan Lahan Pekarangan Mendukung Peningkatan Produksi Buahbuahan Di Sumatera Barat. Prosiding Seminar Nasional Hortiklutura. http://sumbar.litbang.deptan.go.id./ (diakses tanggal 18 Juli 2018

Lakitan, B. 1995. Hortikuktura: Teori, Budidaya dan Pasca Panen. Jakarta (ID): PT. Raja Grafindo.

Aizeh, M., Setiawan, 2012. Pengelompokan Kecamatan di Pulau Madura Berdasarkan Sektor Pertanian sebelum dan setelah Berdiri Jembatan Suramadu. Jurnal Sains Dan Seni ITS Vol. 1, No. 1.

Mulyana, D. 2011. Ekonomi Pekarangan Di Desa Jawa. Komunitas 3(1):19- 28.

Nudin, F. 2016. Keanekaragaman Dan Pemanfaatan Tanaman Pekarangan Di Kabupaten Bangkalan [skripsi]. Bangkalan (ID): Universitas Trunojoyo Madura.

Novitasari, E. 2011. Studi Budidaya Tanaman Pangan Di Pekarangan Sebagai Sumber Ketahanan Pangan Keluarga (studi kasus di Desa Ampel Gading Kecamatan Tirtoyudo Kabupaten Malang) [Skripsi]. Malang (ID): Universitas Brawijaya.

Riah. 2002. Kontribusi Usahatani Lahan Pekarangan Terhadap Ekonomi Rumah Tangga Petani Di Kecamatan Kerinci Kabupaten Pelalawan: Pekanbaru (ID): Universitas Riau.

2005. Pemanfaatan Lahan Pekarangan. Jakarta (ID): Penebar Swadaya. 
Rukmana, H. Rahmat, Y.Y. Oesman. 2002. Rambutan: Komoditas Unggulan dan Prospek Agribisnis. Yogyakarta (ID): Kanisius.

Sopiah, P. 2006. Menghijaukan Pekarangan Dengan Tanaman yang Bermanfaat. Jakarta (ID): PT Sinergi Pustaka.
Vitriyatul, V. 2012. Laporan Pola Tanam Online] http: //blog. ub.ac.id/ fitafitriya/2012/06/26/laporan-pola-tanam/. Diakses pada tanggal 10 Juli 2018.

Wurianingsih, M. 2011. Studi karakteristik dan fungsi pekarangan di Desa Pasir Eurih Kecamatan Taman Sari Kabupaten Bogor. Bogor (ID): Skripsi IPB. 